\title{
Stategi Pengembangan Usaha Produksi Kue Pada Kelompok Wanita Tani Ayu Tangkas Di Kecamatan Selemadeg Timur, Bali
}

\author{
Pande Komang Suparyana $^{1^{*}}$, Ni Putu Sukanteri ${ }^{2}$, Dudi Septiadi ${ }^{3}$ \\ ${ }^{1,3}$ Program Studi Agribisnis, Fakultas Pertanian, Universitas Mataram, Mataram \\ ${ }^{2}$ Program Studi Agribisnis, Fakultas Pertanian, Universitas Mahasaraswati Denpasar, Denpasar \\ $1,3 \mathrm{JI}$. Majapahit No. 62, Mataram \\ ${ }^{2} \mathrm{JI}$. Kamboja No. 11A, Denpasar \\ *E-mail: pandesuparyana@unram.ac.id
}

\begin{abstract}
ABSTRAK
Penelitian ini bertujuan mengidentifikasi kondisi internal dan lingkungan eksternal dari usaha kue di KWT Ayu Tangkas, serta menentukan strategi dalam pengembangan usaha kue di KWT Ayu Tangkas. Pemilihan responden dengan metode purposive sampling, dengan jumlah 21 responden. Penelitian ini berjenis penelitian deskriptif dengan pendekatan manajemen strategi terdiri dari: 1) Tahap pengumpulan data (Input Stage) dengan menggunakan matriks Internal Factor Evaluation (IFE) dan External Factor Evaluation (EFE); 2) Tahap analisis (Matching Stage) dengan menggunakan matriks Internal External (IE) dan matriks Strength, Weakness, Opportunities, and Threats (SWOT); dan 3) Tahap pengambilan keputusan (Decision Stage) dengan pengambilan keputusan menggunakan Quantitative Strategic Planning Matrix (QSPM). Hasil penelitian menunjukkan kondisi internal yaitu: Kualitas dari produk, Harga terjangkau, Hubungan pengurus dengan anggota, Produk sudah dikenal masyarakat, Ketersediaan Bahan Baku, Rendahnya Kualitas SDM, Keterbatasan memperoleh modal, Keterbatasan mendapatkan informasi pasar, Jenis produk 1 macam, dan Kurangnya promosi. Sedangkan Lingkungan eksternal yaitu: Bendu jajanan Khas Daerah Setempat, Permintaan Bendu, Perhatian Institusi pada KWT, Perkembangan Sistem Informasi, Teknologi Produksi, Kemudahan dalam duplikasi produk oleh pesaing, Munculnya Pesaing baru, Naiknya harga Bahan Baku, Keterbatasan waktu dengan kegiatan adat, dan Perubahan selera konsumen. Strategi tebaik yaitu memberikan pelatihan dan penyuluhan Manajemen produksi.
\end{abstract}

Kata kunci: KWT Ayu Tangkas, Strategi Pengembangan Usaha

\begin{abstract}
This study aims to identify the internal and external environmental conditions, and determine the strategy in developing a cake business in KWT Ayu Tangkas. Selection of respondents by purposive sampling method, with a total of 21 respondents. This research is a descriptive study with a strategy management approach consisting of: 1) Data collection stage using the Internal Factor Evaluation and External Factor Evaluation matrices; 2) Matching Stage using the Internal External matrix and the Strength, Weakness, Opportunities and Threats matrix; and 3) Decision Stage with decision making using the Quantitative Strategic Planning Matrix. The results showed internal conditions, namely: Quality of the product, Affordable price, Relationship of the management with members, Products already known to the public, Availability of Raw Materials, Low Quality of Human Resources, Limitations on getting capital, Limitations on getting market information, Type of product 1 type, and Lack of promotion. Whereas the external environment, namely: Local Typical Snack Bendu, Bendu Demand, Institutional Attention at KWT, Information System Development, Production Technology, Ease in product duplication by competitors, Emergence of new Competitors, Rising Raw Material prices, Time constraints with customary activities, and Changes consumer tastes. The best strategy is to provide training and counseling on production management.
\end{abstract}

Keywords:KWT Ayu Tangkas, Business Development Strategy

\section{PENDAHULUAN}

Sektor pertanian merupakan kegiatan usaha yang tidak terkena dampak krisis ekonomi. Tanaman pangan merupakan pertanian strategis di Indonesiayang dapat memenuhikebutuhan pokok, yaitu bahan pangan, sehingga membuat tanaman pangan ini dapat memenuhi kebutuhan lebih dari $63 \%$ masyarakat Indonesia (Balitsereal dan Puslitbang Tanaman Pangan, 2007). Dalam 
pelaksanaan pertanian di Indonesia terdapat permasalahan yang perlu dilakukan penanganan untuk menanggulangi permasalahan tersebut. Bentuk penangan yang dilakukan oleh pemerintah adalah dengan membentuk kelompok tani untuk mempermudah proses pembinaan dan penyuluhan terhadap kegiatan pertanian. Kegiatan tersebut diharapkan dapat meningkatkan kesejahteraan para petani.

Kecamatan selemadeg timur merupakan daerah yang strategis karena sebagai salah satu penghasil padi yang potensial di Kabupaten Tabanan. Disamping itu potensi agrowisata juga merupakan kegiatan unggulan di kecamatan selemadeg timur dengan didukung kawasan pertanian dan sumber daya alam yang indah. Kecamatan Selemadeg Timur terdiri dari 10 desa dinas yang salah satunya merupakan desa megati. Kelompok Tani yang terdapat di desa megati sangat produktif dalam melaksanakan kegiatan usaha taninya. Hal tersebut dapat dilihat dari luas panen yang tertinggi di Kecamatan Selemadeg timur sebanyak $42 \mathrm{Ha}$ (Badan Pusat Statistik Kabupaten Tabanan, 2018).

Kelompok Tani adalah kumpulan petani dengan ikatantidak formal yang terbentuk dari persamaan kepetingan, situasi lingkungan dan memiliki tujuan dalam peningkatan usaha bersama dalam perkumpulannya(Setiyanti, 2012). Tujuan dibentuknya kelompok tani adalah meningkatkan jumlah kelompok tani, meningkatkan kemampuan kelompok tani dalam menjalankan fungsinya dan mendorong kelompok tani meningkatkan kapasitasnya menjadi kelembagaan ekonomi petani. Tujuan kelompok tani dapat diwujudkan melalui pelaksanaan fungsinya. Terdapat tiga fungsi dari kelompok tani yaitu sebagai fungsi sebagai kelas belajar, fungsi sebagai wahana kerjasama, dan fungsi sebagai unit produksi. Ketiga fungsi tersebut dilakukan dengan maksimal agar tercapai tujuan dibentuknya organisasi pertanian ini (Peraturan Menteri Pertanian Tentang Pedoman Pembinaan Kelompok Tani dan Gabungan Kelompok Tani, 2013).

Peranan wanita sebagai ibu rumah tangga mulai berubah sejak era globalisasi, dimana wanita saat ini secara langsung juga turut dalam membantu mencukupi kebutuhan rumah tangga. Tenaga kerja wanita tani memiliki produktivitas yang berperan dan berpotensi dalam mendukung peningkatan pendapatan rumah tangga pertanian di pedesaan. Untuk melakukan pembinaan terhadap produktivitas wanita tani, diperlukan suatu wadah berupa KWT yang dapat dimanfaatkan oleh wanita tani. KWT termasuk dalam salah satu organisasi dalam Kelompok Tani. KWT merupakan kepanjangan dari Kelompok Wanita Tani dengan kesamaan tujuan dalam kegiatan organisasi tersebut. Kelompok ini merupakan kumpulan wanita-wanita yang menjadi satu organisasi di bidang pertanian, baik dalam kegiatan budidaya sampai pada pengolahan produk.

Pengembangan suatu usaha dipengaruhi oleh manajemen dalam organisasi. Organisasi berperan dalam menentukan strategi dalam mengelola usahanya. Sasaran-sasaran kerja yang menjadi tujuan organisasi dilakukan berdasarkan landasan yang telah ditentukan untuk menjalankan strategi pengembangan. Sehingga diperlukan penilaian untuk mengukur kekuatan dan kelemahan dalam suatu usaha yang dapat digunakan untuk perbaikan organisasi pada masa yang akan datang. Hal tersebut diperlukan untuk menghadapi persaingan usaha yang semakin kuat.

Perkembangan kelembagaan pertanian di Bali memunculkan banyak organisasi pertanian. KWT Ayu Tangkas adalah organisasi Wanita Tani yang terdapat di Desa Megati. Organisasi Wanita Tani ini memproduksi komoditas daerahnya menjadi 
produk olahan kue. Dengan berbagai masalah dan kendala yang dihadapi KWT dalam pengembangan usahanya, sehingga perlu dilakukan penelitian untuk mengkaji strategi usaha yang perlu dilakukan oleh KWT Ayu Tangkas dalam mengembangkan usaha produksi kue.

Adapun tujuan dari penelitian ini adalah untuk mengidentifikasi kondisi internal dan lingkungan eksternal dari usaha kue di KWT Ayu Tangkas, serta menentukan strategi yang dapat digunakan KWT Ayu Tangkas dalam pengembangan usaha kue di KWT Ayu Tangkas.

\section{METODE PENELITIAN}

\section{Lokasi dan Waktu Penelitian}

Penelitian ini dilakukan di Desa Megati, Kecamatan Selemadeg Timur, Kabupaten Tabanan pada Kelompok Wanita Tani Ayu Tangkas. Pemilihan Kelompok Wanita Tani ini dilakukan secara sengaja (purposive), peneliti memilih Kelompok Wanita ini dengan pertimbangan KWT ayu Tangkas merupakan satu-satunya KWT di Desa Megati yang melakukan produksi kue bendu dan berdasarkan potensi yang dimiliki Kelompok Wanita Tani dalam pengembangan usaha kue bendu di desa Megati. Waktu penelitian dilaksanakan pada bulan Mei sampai dengan Juli 2019.

\section{Responden Penelitian}

Responden dalam penelitian ini berjumlah 21 responden yang terdiri dari 3 responden Pengurus KWT Ayu Tangkas, 12 responden Anggota KWT Ayu Tangkas, 5 responden Pelanggan kue KWT Ayu Tangkas, dan 1 responden PPL KWT Ayu Tangkas. Pemilihan responden penelitian ini dilakukan dengan metode purposive sampling, teknik ini digunakan dengan pertimbangan bahwa responden yang dipilih merupakan subyek pelaku yang melakukan kegiatan dalam usaha di Kelompok Wanita Tani Ayu Tangkas.

\section{Analisis Data}

Penelitian ini berjenis penelitian deskriptif dengan pendekatan manajemen strategi. Alternatif strategi yang dirumuskan dalam mengembangkan usaha produksi kue pada Kelompok Wanita Tani Ayu Tangkas dilakukan dengan menggunakan matriks. Proses perumusan alternatif strategi melalui tiga tahap yaitu : 1) Tahap pengumpulan data (Input Stage) dengan menggunakan matriks Internal Factor Evaluation (IFE) dan External Factor Evaluation (EFE); 2) Tahap analisis (Matching Stage) dengan menggunakan matriks Internal External (IE) dan matriks Strength, Weakness, Opportunities, and Threats (SWOT); dan 3) Tahap pengambilan keputusan (Decision Stage) dengan pengambilan keputusan menggunakan Quantitative Strategic Planning Matrix (QSPM)(Rangkuti, 2015).

\section{HASIL DAN PEMBAHASAN}

\section{Karakteristik Kelompok Wanita Tani Ayu Tangkas}

Desa Megati terletak di Kecamatan Selemadeg Timur Kabupaten Tabanan memiliki posisi yang sangat strategis karena berada pada jalur nasional Denpasar Gilimanuk sekitar $90 \mathrm{~km}$ dari Denpasar. Dengan posisi yang strategis ini maka Desa Megati sangat potensial untuk dikembangkan sebagai Desa Bumdes yaitu desa yang mengelola produk-produk lokal menjadi bahan yang siap konsumsi melalui pembinaan kelompok-kelompok usahapada bermacam jenis industri rumah tangga (IRT) yang ada.Desa Megati merupakan salah satu desa yang mengadakan pemberdayaan perempuan khususnya bagi ibu-ibu petani melalui program Kelompok Wanita Tani (KWT). KWT dijadikan sebagai tempat berkumpul dan bekerjasama untuk petani wanita dalam pengolahan lahan pertanian sehingga dapat memberikan hasil panen yang lebih optimal bagi keluarga dan 
masyarakat didaerahnya. Disinilah ibu-ibu dibimbing dan diberi pengetahuan tentang pengelolaan lahan pertanian serta pengolahan makanan dari produk pertanian. Pengetahuan yang didapatkan selama pembimbingan tersebut membuat ibu-ibu keterampilan yang lebih dalam melakukan pengolahan lahannya.KWT diharapkan dapat membuat produk-produk lokal desa menjadi produk unggulan daerahnya, sehingga dapat meningkatkan kemampuan ekonomi kelompok khususnya dan secara umum meningkatkan ekonomi masyarakat desa.

KWT Ayu Tangkas merupakan kelompok wanita tani yang bergabung dalam pengolahan hasil pertanian dalam bentuk kue-kue lokal dan pengolahan hasil pertanian dalam bentuk menu pendamping nasi. Kue yang diolah setiap hari merupakan kue yang dibutuhkan masyarakat setemapt, selebihnya KWT ini menyediakan kue yang dibutuhkan untuk kebutuhan upacara. Permasalahan pada KWT Ayu Tangkas adalah minimnya sarana yang digunakan dalam berproduksi, tidak beragamnya jenis kue yang dihasilkan dan kurangnya variasi pada kue yang dibuat, serta pemasaran yang relatif rendah. Pemasaran kue yang diproduksi oleh KWT Ayu Tangkas, hanya menunggu pemesan yang datang saat upacara. Hal tersebutdikarenakan belum dikenalnya produk secara luas oleh masyarakat sekitar.

Tabel 1. Karakteristik KWT Ayu Tangkas berdasarkan Umur di Desa Megati

\begin{tabular}{cccc}
\hline No & Kelompok Umur & Jumlah Anggota & Persentase \\
\hline 1 & $38-42$ & 9 & $60,00 \%$ \\
2 & $43-47$ & 4 & $26,67 \%$ \\
3 & $48-52$ & 1 & $6,67 \%$ \\
4 & $53-57$ & 0 & $0,00 \%$ \\
5 & $58-64$ & 1 & $6,67 \%$ \\
\hline \multicolumn{5}{c}{ Total } & 15 & $100,00 \%$ \\
\hline
\end{tabular}

Sumber: Data primer diolah, 2019

Jumlah KWT Ayu Tangkas berjumlah 15 wanita dengan komposisi 1 orang menjabat sebagai ketua, 1 orang sebagai sekretaris, 1 orang sebagai bendahara dan 13 orang anggota. Dapat dilihat pada tabel 1, mayoritas umur KWT Ayu Tangkas berkisar antara 38-42 tahun. Umur 38-42 tahun merupakan usia yang masih produktif dan memiliki semangat jiwa berwirausaha yang dapat meningkatkan pendapatan keluarga.

Tingkat pendidikan dapat digunakan tolak ukur dari kemampuan dan pengetahuan seseorang. Hal ini sejalan bahwa semakin tinggi tingkat pendidikan yang dicapai, maka seseorang akan lebih memperhatikan manajemen produksi dalam menghasilkan produk dikarenakan pengetahuan yang dimilikinya. Tabel 2 menunjukkan tingkat pendidikan mayoritas KWT Ayu Tangkas pada tingkat SMP. Tingkat pendidikan yang bervariasi pada KWT Ayu Tangkas dari SD sampai Perguruan tinggi mengindikasikan pola pikir yang baik saat melakukan musyawarah dalam pengaturan dan manajemen usaha. 
Suparyana, dkk. 2020

Tabel 2. Karakteristik KWT Ayu Tangkas berdasarkan Pendidikan di Desa Megati

\begin{tabular}{cccc}
\hline No & Tingkat Pendidikan & Jumlah Anggota & Persentase \\
\hline 1 & SD & 3 & $20,00 \%$ \\
2 & SMP & 9 & $60,00 \%$ \\
3 & SMA & 2 & $13,33 \%$ \\
4 & SARJANA & 1 & $6,67 \%$ \\
\hline & Total & 15 & $100,00 \%$
\end{tabular}

Sumber: Data primer diolah, 2019

Pada tabel 3 dapat dilihat Kelompok Wanita Tani memiliki kegiatan rutin mayoritas sebagai karyawan swasta dan lbu Rumah Tangga. Kombinasi pekerjaan tersebut dapat digunakan dalam pembagian tugas, dimana sesama anggota dapat mengatur pembagian tugas sesuai dengan kesibukan masingmasing. Untuk Ibu Rumah Tangga dapat melakukan kegiatan pada pagi hari dan Karyawan swasta dapat melakukan kegiatan setelah pulang bekerja disaat sore hari.

Tabel 3. Karakteristik KWT Ayu Tangkas berdasarkan Pekerjaan Utama di Desa Megati

\begin{tabular}{clcc}
\hline No & Pekerjaan Utama & Jumlah Anggota & Persentase \\
\hline 1 & Ibu Rumah Tangga & 5 & $33,33 \%$ \\
2 & Petani & 1 & $6,67 \%$ \\
3 & Pedagang & 4 & $26,67 \%$ \\
4 & Karyawan Swasta & 5 & $33,33 \%$ \\
\hline & Total & 15 & $100,00 \%$
\end{tabular}

Sumber: Data primer diolah, 2019

KWT Ayu Tangkas memiliki struktur organisasi dan tugas masing-masing yang telah disepakati bersama saat menyusun AD/ART KWT Ayu Tangkas. KWT Ayu Tangkas dipimpin oleh seorang ketua yang memiliki tugas sebagai penanggungjawab kegiatan dan mengkoordinasikan anggota KWT, sehingga dapat bersama-sama memajukan dan mengembangkan kegiatan ekonomi KWT. Sekretaris bertugas dalam mencatat segala kegiatan dan mengarsipkan dokumen-dokumen KWT. Bendahara bertugas dalam pencatatan serta pembukuan pemasukan dan pengeluaran kegiatan KWT.

\section{Matriks IFE dan EFE}

Matrix IFE dan EFE merupakan tahap pertama dalam melakukan perumusan strategi. Tahap ini disebut sebagai tahap input yang berfungsi untuk mengidentifikasi dan menyusun informasi tentang berbagai macam daftar peluang dan ancaman yang dihasilkan dari melakukan audit/penilaian terhadap lingkungan eksternal perusahaan. Tidak hanya itu, informasi dasar ini juga berisi sekumpulan daftar kekuatan dan kelemahan yang dimiliki oleh perusahaan yang merupakan hasil dari audit/penilaian lingkungan internal perusahaan. Hasil perhitungan faktor-faktor internal dan eksternal strategi pengembangan usaha pada KWT Ayu Tangkas di Desa Megati dapat dilihat pada Tabel 4 dan 5.

Berdasarkan Tabel 4, bahwa faktor kekuatan yang diharapkan dapat meminimalkan faktor kelemahan dalam pengembangan usaha pada KWT Ayu Tangkas di Desa Megati yaitu dengan penerapan kualitas dari produk. Faktor tersebut mendapatkan skor tertinggi yang diperoleh yaitu 0,39 dengan bobot 0,10 dan rating 3,71 . Faktor kekuatan dengan skor terendah yaitu hubungan pengurus dengan 
anggota dan ketersediaan bahan baku dengan skor 0,27.

Faktor internal kelemahan yang dihadapi dalam pengembangan usaha pada KWT Ayu Tangkas di Desa Megati terbesar yaitu rendahnya kualitas SDM yang memiliki skor 0,30. Faktor internal kelemahan dengan skor terendah yaitu keterbatasan mendapatkan informasi pasar dan kurangnya promosi dengan skor 0,23.

Faktor yang menjadi kekuatan utama dalam pengembangan usaha pada KWT Ayu Tangkas di Desa Megati yaitu penerapan kualitas dari produk. Kualitas dari produk yang baik akan menjaga mutu produk. Tujuannya untuk menjaga agar mutu produk kue yang dihasilkan KWT selalu bagus baik kualitas rasa dan bentuknya. Kelemahan utama dalam pengembangan usaha pada KWT Ayu Tangkas di Desa Megati adalah rendahnya kualitas SDM KWT. Untuk menanggulangi kelemahan tersebut perlu dilakukan pemberian pelatihan dan penyuluhan kepada seluruh anggota KWT mengenai manajemen dan produksi yang baik dalam melakukan usaha pembuatan kue.

Tabel 4. Matriks IFE Pengembangan Usaha pada KWT Ayu Tangkas di Desa Megati

\begin{tabular}{clrrr}
\hline No & \multicolumn{1}{c}{ Faktor-faktor Strategi Internal } & Bobot & Rating & B x R \\
\hline A & Kekuatan (Strength) & & & \\
1 & Kualitas dari produk & 0,10 & 3,71 & 0,39 \\
2 & Harga terjangkau & 0,10 & 3,00 & 0,31 \\
3 & Hubungan pengurus dengan anggota & 0,09 & 2,90 & 0,27 \\
4 & Produk sudah dikenal masyarakat & 0,08 & 3,48 & 0,29 \\
5 & Ketersediaan Bahan Baku & 0,09 & 3,10 & 0,27 \\
\hline B & Kelemahan (Weaks) & & \\
1 & Rendahnya Kualitas SDM & 0,11 & 2,76 & 0,30 \\
2 & Keterbatasan memperoleh modal & 0,11 & 2,24 & 0,25 \\
& Keterbatasan mendapatkan informasi & & & \\
3 & pasar & 0,09 & 2,52 & 0,23 \\
4 & Jenis produk 1 macam & 0,11 & 2,67 & 0,29 \\
5 & Kurangnya promosi & 0,11 & 2,10 & 0,23 \\
\hline \multicolumn{2}{c}{ Total } & 1,00 & & 2,83 \\
\hline
\end{tabular}

Sumber: Data primer diolah, 2019

Berdasarkan Tabel 5, bahwa faktor peluang yang terbaik dalam pengembangan usaha pada KWT Ayu Tangkas di Desa Megati yaitu permintaan kue bendu. Faktor tersebut mendapatkan skor tertinggi yang diperoleh yaitu 0,41 dengan bobot 0,12 dan rating 3,52 . Faktor peluang dengan skor terendah yaitu perkembangan system informasi dengan skor 0,24.

Faktor ancaman tertinggi yang dihadapi dalam pengembangan usaha pada KWT Ayu Tangkas di Desa Megati yaitu keterbatasan waktu dengan kegiatan adat yang memiliki skor 0,27. Faktor peluang dengan skor terendah yaitu perubahan selera konsumen dengan skor 0,17.

Faktor peluang yang baik dalam pengembangan usaha pada KWT Ayu Tangkas di Desa Megati yaitu permintaan kue bendu. Permintaan yang tinggi terhadap kue bendu membuat usaha KWT berjalan dengan lancar. Peluang ini harus tetap dijaga dengan memberikan produk terbaik kepada konsumen. Faktor ancaman yang besar dalam pengembangan usaha pada KWT Ayu Tangkas di Desa Megati yaitu keterbatasan 
Suparyana, dkk. 2020

waktu dengan kegiatan adat. Untuk menanggulangi hal tersebut diperlukan manajemen waktu dan penjadwalan kerja yang baik dalam melakukan produksi, sehingga kegiatan produksi tetap berjalan ketika ada kegiatan adat di Desa tersebut.

Tabel 5. Matriks EFE Pengembangan Usaha pada KWT Ayu Tangkas di Desa Megati

\begin{tabular}{clrrr}
\hline No & \multicolumn{1}{c}{ Faktor-faktor Strategi Eksternal } & Bobot & Rating & B x R \\
\hline A & Peluang (Oppurtunities) & & & \\
1 & Bendu jajanan Khas Daerah Setempat & 0,11 & 3,52 & 0,40 \\
2 & Permintaan Bendu & 0,12 & 3,52 & 0,41 \\
3 & Perhatian Institusi pada KWT & 0,10 & 2,86 & 0,29 \\
4 & Perkembangan Sistem Informasi & 0,08 & 3,05 & 0,24 \\
5 & Teknologi Produksi & 0,11 & 2,62 & 0,30 \\
\hline B & Ancaman (Threats) & & & \\
& Kemudahan dalam duplikasi produk oleh & 0,13 & 1,76 & 0,22 \\
1 & pesaing & 0,07 & 2,62 & 0,18 \\
2 & Munculnya Pesaing baru & 0,10 & 1,90 & 0,19 \\
3 & Naiknya harga Bahan Baku & 0,11 & 2,48 & 0,27 \\
4 & Keterbatasan waktu dengan kegiatan adat & 0,07 & 2,48 & 0,17 \\
5 & Perubahan selera konsumen & 1,00 & & 2,68 \\
\hline & $\quad$ Total & &
\end{tabular}

Sumber: Data primer diolah, 2019

\section{Matriks IE}

Fungsi dari penggunaan Matriks IE adalah untuk mengetahui posisi saat ini usaha pada KWT Ayu Tangkas. Pemilihan strategi sangat ditentukan oleh pemetaan posisi usaha pada KWT Ayu Tangkas. Berdasarkan analisis matriks IFE diperoleh total skor 2,83 dan total skor EFE yaitu sebesar 2,68.

Total Skor IFE 2,83

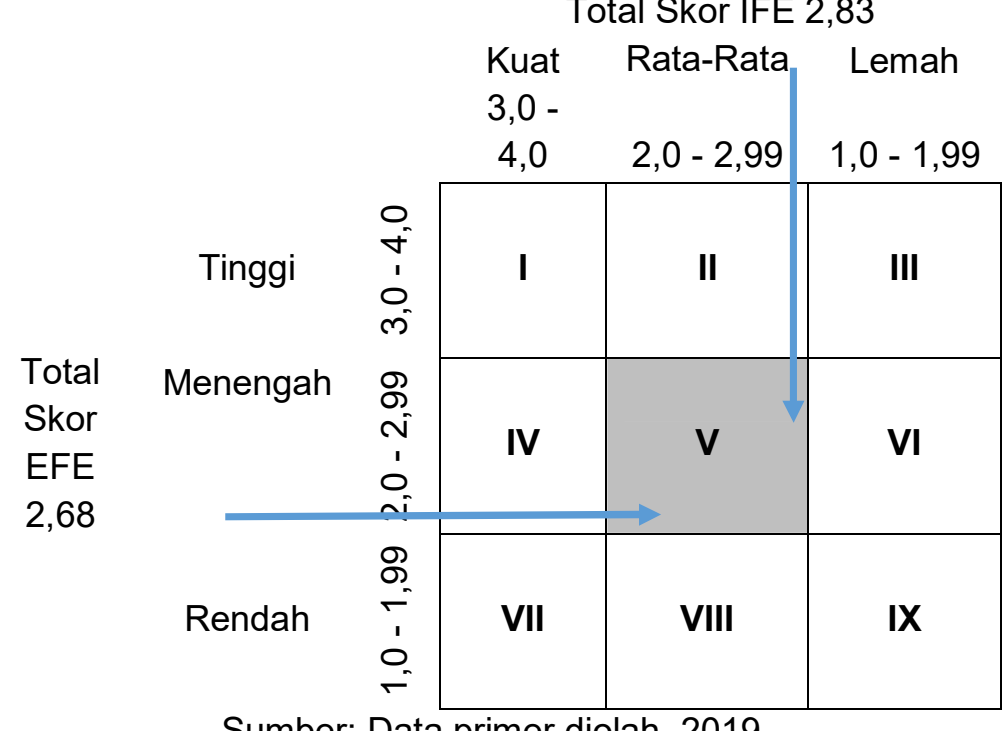

Sumber: Data primer diolah, 2019

Gambar 1. Matriks IE Pengembangan Usaha pada KWT Ayu Tangkas di Desa Megati 
Dari kedua matriks tersebut yaitu IFE dan EFE, kemudian disatukan dalam matriks IE.Matriks IE usaha pada KWT Ayu Tangkas dapat dilihat pada Gambar 1. Hasil tersebut menempatkan usaha pada KWT Ayu Tangkas pada posisi sel V. Strategi yang digunakan pada sel $\mathrm{V}$ ini adalah strategi mempertahankan dan pemeliharaan (hold and maintain). Penetrasi pasar dan pengembangan produk merupakan dua strategi yang cocok digunakan pada daerah ini (David, 2004).

Strategi penetrasi pasar yaitu usaha untuk meningkatkan pangsa pasar atau market share suatu produk atau jasa yang sudah ada di pasar melalui pemasaran yang lebih gencar(David, 2004). Penetrasi pasar mencakup peningkatkan jumlah tenaga penjual, menawarkan promosi penjualan yang ekstensif atau meningkatkan usaha publisitas. Untuk meningkatkan pangsa pasar produk kue bendu, KWT Ayu Tangkas dapat melakukan strategi dengan merangsang pelanggan untuk membeli produk lebih banyak lagi maupun meningkatkan jumlah tenaga penjual (distributor). Strategi tersebut dapat dilakukan melalui promosi penjualan dengan media sosial atau promosi penjualan yang ekstensif, misalnya dengan memberikan bonus tambahan produk untuk pembelian dalam jumlah yang banyak. Strategi lain yangdapat dilakukan yaitu dengan memberikan pelayanan yang lebih baik, seperti ketersediaan produk yang kontinyu, kualitas produk yang konsisten, pengiriman tepat waktu dan sesuai pesanan, serta keramahan kepada pelanggan ketika membeli.

Strategi pengembangan produk merupakan strategi peningkatan penjualan dengan cara meningkatkan dan memodifikasi produk-produk atau jasa yang ada saat ini (David, 2004). Strategi pengembangan produk dilakukan dengan tujuan untuk meningkatkan daya saing. Diferensiasi produk dengan memperluas lini produk yang akan dijual, baik dari variasi, bentuk dan kualitas kemasan yang akan berdampak pada semakin banyaknya pilihan yang ditawarkan kepada konsumen sehingga konsumen merasa puas.

\section{Matriks SWOT}

Matriks SWOT dapat memberikan gambaran terhadap manajemen dalam pencocokan kekuatan dan kelemahan internal KWT dengan peluang-peluang dan ancaman-ancaman eksternal yang dihadapi KWT. Tujuan dari tahap pencocokan (matriks SWOT) ini yaitu untuk menghasilkan alternatif strategi yang layak, bukan untuk memilih strategi yang terbaik. Sehingga tidak semua strategi yang dikembangkan dalam matriks SWOT akan dipilih untuk implementasi. Empat strategi utama yang disarankan yaitu strategi SO (Strengths-Opportunities), WO (Weakness-Opportunities), ST (StrengthsThreats) dan WT (Weakness- Threats). Analisis ini menggunakan data yang telah diperoleh dari matriks IFE dan EFE diatas. Hasil analisis matriks SWOT usaha pada KWT Ayu Tangkas dapat dilihat pada Gambar 2.

Strategi S-O adalah strategi yang menggunakan kekuatan internal usaha pada KWT Ayu Tangkas untuk memanfaatkan peluang eksternal yang ada agar memperoleh keuntungan bagi usaha pada KWT Ayu Tangkas. Terdapat satu alternatif strategi yang dapat dilakukan pada strategi S-O yaitu meningkatkan volume penjualan. Strategi ini dapat dilakukan dengan mencari lokasi baru dan meningkatkan jumlah lokasi pemasaran. Banyaknya pasar tradisional dan modern di Kota tabanan dapat dijadikan potensi untuk memasarkan produknya pada tempat tersebut dengan dukungan dari Dinas Pertanian Kabupaten Tabanan. Strategi tersebut dapat menjadikan usaha KWT bersaing dengan produk sejenis dari 
produsen lain. Selain itu, adanya peningkatan wisatawan merupakan salah satu potensi untuk dapat meningkatkan permintaan akan produk usaha KWT. Hal ini didukung juga dengan adanya kemudahan usaha KWT dalam memperoleh bahan baku, sehingga dapat berproduksi sepanjang waktu. Hal lain yang dapat dilakukan oleh usaha KWT untuk memperluas pasar yaitu dengan memanfaatkan perkembangan teknologi yang ada untuk mempromosikan produk melalui internet. Adanya internet pun dapat menambah informasi melalui penelusuran mengenai tren perkembangan produk di pasar, khususnya produk kue yang tren dipasaran. Hal tersebut dapat memotivasi KWT untuk dapat lebih berkreasi dalam hal variasi produk kue, misalnya dengan lebih menonjolkan kekhasan produk usaha KWT sehingga digemari oleh para konsumen.

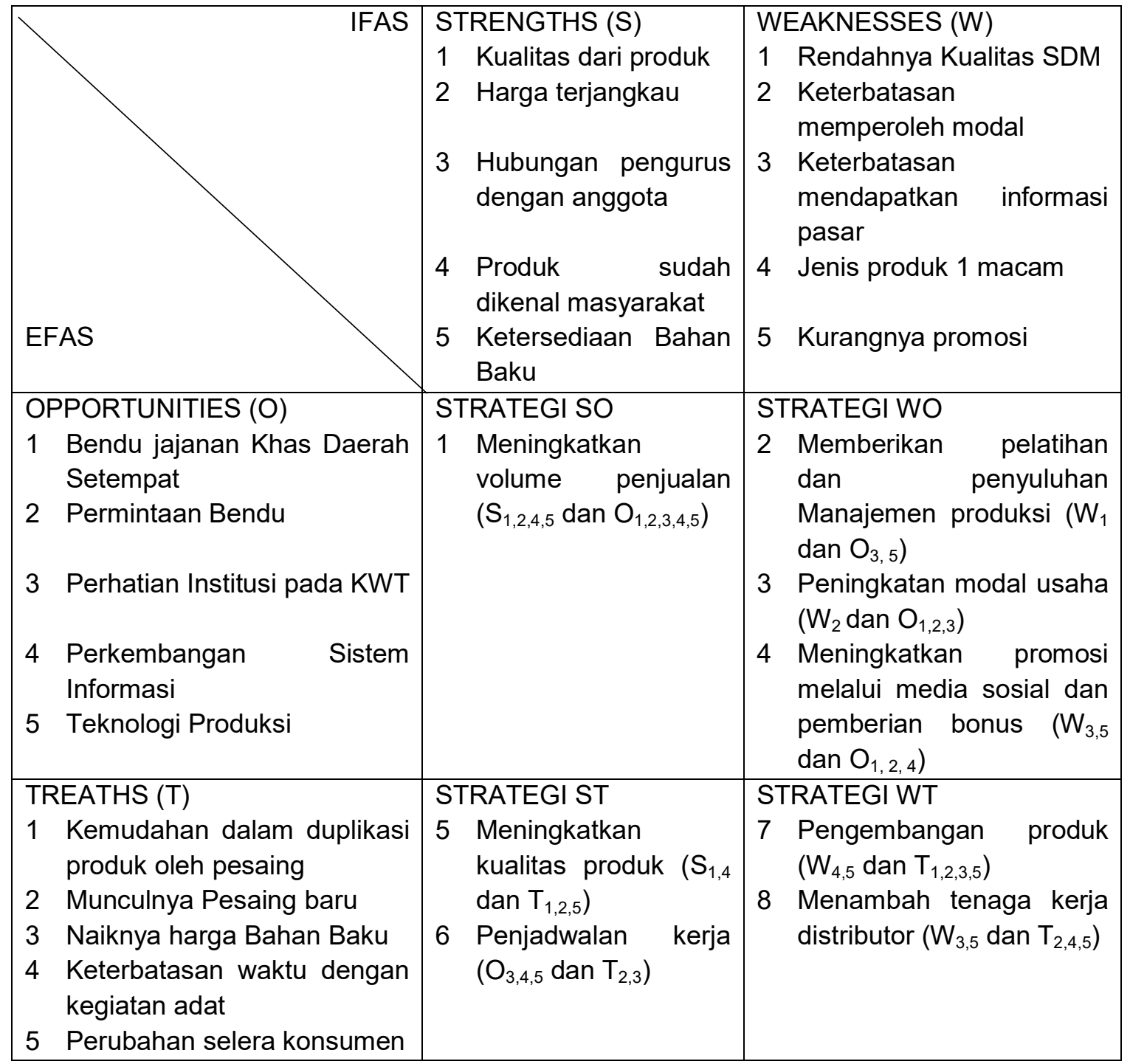

Sumber: Data primer diolah, 2019

Gambar 2. Matriks SWOT Pengembangan Usaha pada KWT Ayu Tangkas di Desa Megati 
Strategi W-O adalah strategi bertujuan untuk mengatasi kelemahaninternal dengan memanfaatkan peluang eksternal yang dimiliki oleh usaha pada KWT Ayu Tangkas. Ada tiga alternatif strategi yang dapat dilakukan pada strategi W-O, yaitu:

1. Memberikan pelatihan dan penyuluhan Manajemen produksi

Pelatihan dan penyuluhan

Manajemen produksi dapat meningkatkan kualitas SDM KWT Ayu Tangkas. Dalam penelitian mengenai pengaruh frekuensi mengikuti penyuluhan dengan peningkatan produktivitas(Guruh Julio et al., 2014), disimpulkan bahwa penyuluhan dapat memberikan pengetahuan dalam meningkatkan produksi dengan menerapkan teknologi.

2. Peningkatan modal usaha

Keterbatasan modal merupakan faktor yang dapat menghambat dalam perkembangan usaha. Apabila modal meningkat, maka usaha KWT dapat memenuhi permintaan pelanggan terhadap produk dan memperluas pemasarannya.Sejalan dengan penelitian pengaruh modal terhadap pertumbuhan usaha(Endang Purwanti, 2012; Safitri \& Setiaji, 2018), disimpulkan bahwa modal sebagai pendukung dalam menjalankan usaha untuk menyediakan input yang digunakan dalam produksi

3. Meningkatkan promosi melalui media sosial dan pemberian bonus

Strategi promosi melalui media sosial dan kerjasama pada kawasan wisata dengan memberikan tester dan bonusproduk jika membeli dalam jumlah yang banyak diharapkan dapat meningkatkan penjualan. Dengan mengoptimalkan promosi maka produk yang ditawarkan oleh KWT akan lebih dikenal oleh masyarakat.Strategi ini sejalan dengan penelitian yang dilakukan olehIndika \& Jovita(2017); Indrawati et al.(2017); Reinhart Abedneju Sondakh et al.(2019); Setiawan et al.(2019); Untari \& Fajariana(2018) yang menyatakan media sosial dapat digunakan untuk mempromosikanproduk sehingga memberi peningkatan penjualan

Strategi S-T ini menggunakan kekuatan internal usaha pada KWT Ayu Tangkas untuk menghindariatau mengurangi pengaruh dari ancaman eksternal usaha pada KWT Ayu Tangkas. Terdapat dua alternatif strategi yang dapat dilakukan pada strategi S-T yaitu:

1. Meningkatkan kualitas produk

Kualitas produk KWT ditentukan oleh bahan baku yang digunakan dan proses yang dikerjakan dengan baik. Oleh karena itu, KWT harus tetap konsisten dengan penggunaan bahan baku dan proses yang standar agar kualitas produk yang dihasilkan tetap terjaga dengan baik. Perusahaan dalam bertahan dan berkembang harus mampu mempertahankan serta meningkatkan kualitas produknya sehingga dapat bersaing di pasaran (Purwono et al., 2008)

2. Penjadwalan kerja

Penjadwalan yang baik akan berdampak pada produksi yang dilakukan secara kontinyu dan menghasilkan tingkatpenjualan yang tinggi bila dibandingkan dengan produksi yang hanya berdasarkan pesanan saja. Proses produksi sangat bergantung pada ketersediaan bahan baku. KWT memiliki potensi untuk berproduksi secara kontinyu, hal tersebut didukung dengan adanya kemudahan dalam memperoleh bahan baku.

Strategi W-T adalah strategi yang diarahkan pada pengurangan kelemahan internal dan menghindari ancaman eksternal. Terdapat dua alternatif strategi yang dapat dilakukan pada strategi $\mathrm{W}-\mathrm{T}$ yaitu:

1. Pengembangan produk

Pengembangan produk dapat dilakukan KWT dengan memberikan jenis, variasi rasa, bentuk maupun kemasan yang baru pada setiap produk. Jenis kue baru juga perlu ditambahkan untuk memberikan variasi pilihan kepada konsumen jika sudah mulai bosan dengan kue bendu. Variasi rasa dapat 
dikembangkan dengan menambahkan rasa baru pada produk bendu diisi dengan rasa buah-buahan, cokelat maupun keju. Selain itu, KWT pun dapat memberikan variasi dalam bentuk, sehingga dapat meningkatkan daya Tarik terhadap produknya. Dari segi kemasan, KWT dapat menambahkan dengan kemasan modern agar lebih hygienis dan tetap mempertahankan kemasan tradisionalyang dapat didaur ulang. Ukuran kemasan pun sebaiknya disediakan untuk ukuran besar dan kecil agar sesuai dengan kemampuan konsumen dalam pembelian produk.

2. Menambah tenaga kerja distributor

Penambahan tenaga kerja distributor dapat memperluas dan memperkuat jaringan distribusi yang sudah ada. Adapun cara yang dapat dilakukan yaitu dengan mencari dan bekerjasama dengan tenaga distributor yang ada di lokasi strategis dengan system bagi hasil. Dengan begitu, KWT dapat meningkatkan jumlah penjualan.

\section{Matriks QSP}

Matriks Perencanaan Strategi

Kuantitatif (Quantitative Strategic Planning Matrix-QSPM) adalah teknik analisis yang didisain untuk menentukan daya tarik dari alternatif tindakan yang layak(David, 2004). Alternatif strategi yang dihasilkan dari matriks SWOT dapat diterapkan oleh KWT, selanjutnya diprioritaskan dengan menentukan daya Tarik relatif dari berbagai strategi berdasarkan strategi berdasarkan seberapa jauh faktor keberhasilan kunci internal dan eksternal dapat dimanfaatkan atau diperbaiki. Faktor-faktor eksternal dan internal dibandingkan pengaruhnya terhadap daftar strategi yang akan dipilih. Semakin tinggi Total Nilai Daya Tarik (TAS) maka semakin menarik alternatif tersebut sebagai prioritas strategi untuk dilaksanakan oleh KWT. Berdasarkan pengolahan QSPM, diperoleh prioritas strategi yang dapat dijalankan KWT berdasarkan penjumlahan
TAS tertinggi. Hasil matriks QSP disajikan pada Tabel 6.

Pada Tabel 6 terlihat bahwa, strategi yang telah diurutkan merupakan hasil dari pembobotan. Strategi yang memiliki bobot terbesar yang dapat diterapkan oleh KWT yaitu pemberian pelatihan dan penyuluhan Manajemen produksi. Strategi tersebut dapat digunakan untuk meningkatkan SDM KWT yang akan berdampak pada tata kelola organisasi KWT dalam melaksanakan proses manajemen yang baik dalam usahanya.

\section{KESIMPULAN}

Kesimpulan dari penelitian yang telah dilakukan sebagai berikut: 1) Kondisi internal dalam pengembangan usaha KWT yaitu: Kualitas dari produk, Harga terjangkau, Hubungan pengurus dengan anggota, Produk sudah dikenal masyarakat, Ketersediaan Bahan Baku, Rendahnya Kualitas SDM, Keterbatasan memperoleh modal, Keterbatasan mendapatkan informasi pasar, Jenis produk 1 macam, dan Kurangnya promosi. Sedangkan Lingkungan eksternal dalam pengembangan usaha KWT yaitu:Bendu jajanan Khas Daerah Setempat,Permintaan Bendu, Perhatian Institusi pada KWT, Perkembangan Sistem Informasi, Teknologi Produksi, Kemudahan dalam duplikasi produk oleh pesaing, Munculnya Pesaing baru, Naiknya harga Bahan Baku, Keterbatasan waktu dengan kegiatan adat, dan Perubahan selera konsumen. 2)Strategi terbaik yang dapat diterapkan dalam pengembangan usaha produksi kue pada KWT Ayu Tangkas yaitu memberikan pelatihan dan penyuluhan Manajemen produksi.

Saran yang dapat diberikan bagi KWT Ayu Tangkas sebaiknya melakukan strategi memberikan pelatihan dan penyuluhan Manajemen produksi kepada pengurus dan anggota. 
Suparyana, dkk. 2020

Tabel 6. Matriks QSP Pengembangan Usaha pada KWT Ayu Tangkas di Desa Megati

\begin{tabular}{|c|c|c|c|c|c|c|c|c|c|c|}
\hline \multirow{3}{*}{ No } & \multirow{3}{*}{ Faktor-faktor Utama } & \multirow{3}{*}{ Bobot } & \multicolumn{8}{|c|}{ Strategi } \\
\hline & & & 1 & 2 & 3 & 4 & 5 & 6 & 7 & 8 \\
\hline & & & TAS & TAS & TAS & TAS & TAS & TAS & TAS & TAS \\
\hline \multirow[t]{8}{*}{ A } & Kekuatan: & & & & & & & & & \\
\hline & Kualitas dari produk & 0,10 & 0,37 & 0,42 & 0,21 & 0,34 & 0,42 & 0,24 & 0,42 & 0,13 \\
\hline & Harga terjangkau & 0,10 & 0,34 & 0,29 & 0,31 & 0,39 & 0,42 & 0,16 & 0,24 & 0,29 \\
\hline & Hubungan pengurus dengan & & & & & & & & & \\
\hline & anggota & 0,09 & 0,35 & 0,30 & 0,19 & 0,12 & 0,19 & 0,30 & 0,16 & 0,23 \\
\hline & Produk sudah dike & & & & & & & & & \\
\hline & masyarakat & 0,08 & 0,34 & 0,23 & 0,17 & 0,34 & 0,17 & 0,13 & 0,30 & 0,25 \\
\hline & Ketersediaan Baha & 0,09 & 0,35 & 0,19 & 0,26 & 0,09 & 0,26 & 0,28 & 0,26 & 0,22 \\
\hline \multirow[t]{6}{*}{$B$} & Kelemahan: & & & & & & & & & \\
\hline & $\begin{array}{l}\text { Rendahnya Kualitas SDM } \\
\text { Keterbatasan memperoleh }\end{array}$ & 0,11 & 0,27 & 0,35 & 0,22 & 0,11 & 0,32 & 0,24 & 0,14 & 0,14 \\
\hline & $\begin{array}{l}\text { modal } \\
\text { Keterbatasan mendapatkan }\end{array}$ & 0,11 & 0,14 & 0,41 & 0,44 & 0,19 & 0,11 & 0,14 & 0,16 & 0,11 \\
\hline & informasi pasar & 0,09 & 0,11 & 0,34 & 0,28 & 0,37 & 0,09 & 0,09 & 0,11 & 0,32 \\
\hline & Jenis pro & 0,11 & 0,27 & 0,43 & 0,32 & 0,16 & 0,11 & 0,22 & 0,43 & 0,22 \\
\hline & Kurangnya promosi & 0,11 & 0,14 & 0,27 & 0,43 & 0,43 & 0,22 & 0,19 & 0,24 & 0,35 \\
\hline \multirow[t]{7}{*}{$\mathrm{C}$} & Peluang: & & & & & & & & & \\
\hline & Bendu jajana & & & & & & & & & \\
\hline & Setempat & 0,11 & 0,45 & 0,25 & 0,23 & 0,39 & 0,34 & 0,37 & 0,34 & 0,28 \\
\hline & Permintaan Bendu & 0,12 & 0,47 & 0,26 & 0,35 & 0,44 & 0,35 & 0,47 & 0,41 & 0,38 \\
\hline & $\begin{array}{l}\text { Perhatian Institusi pada KWT } \\
\text { Perkembangan Sistem }\end{array}$ & 0,10 & 0,28 & 0,38 & 0,31 & 0,23 & 0,31 & 0,23 & 0,31 & 0,26 \\
\hline & Informasi & 0,08 & 0,16 & 0,26 & 0,31 & 0,28 & 0,16 & 0,20 & 0,22 & 0,26 \\
\hline & Teknologi Produksi & 0,11 & 0,32 & 0,40 & 0,46 & 0,32 & 0,46 & 0,26 & 0,46 & 0,26 \\
\hline \multirow[t]{7}{*}{$\mathrm{D}$} & Ancaman: & & & & & & & & & \\
\hline & Kemudahar & & & & & & & & & \\
\hline & & 0,13 & 0,26 & 0,48 & 0,13 & 0,13 & 0,51 & 0,13 & 0,35 & 0,16 \\
\hline & Munculnya Pesaing baru & 0,07 & 0,26 & 0,20 & 0,07 & 0,07 & 0,27 & 0,07 & 0,27 & 0,26 \\
\hline & Naiknya harga Bahan Baku & 0,10 & 0,15 & 0,26 & 0,41 & 0,10 & 0,31 & 0,18 & 0,31 & 0,10 \\
\hline & Kete & & & & & & & & & \\
\hline & kegiatan adat & 0,11 & 0,19 & 0,38 & 0,22 & 0,11 & 0,11 & 0,43 & 0,11 & 0,35 \\
\hline \multirow[t]{3}{*}{5} & Perubahan selera konsumen & 0,07 & 0,14 & 0,26 & 0,14 & 0,22 & 0,20 & 0,14 & 0,22 & 0,15 \\
\hline & TOTAL & & 5,33 & 6,38 & 5,44 & 4,82 & 5,32 & 4,45 & 5,45 & 4,71 \\
\hline & PERINGKAT & & 4 & 1 & 3 & 6 & 5 & 8 & 2 & 7 \\
\hline
\end{tabular}

Sumber: Data primer diolah, 2019 
DAFTAR PUSTAKA

Badan Pusat Statistik Kabupaten Tabanan. (2018). Kecamatan Selemadeg Timur Dalam Angka 2017. Badan Pusat Statistik Kabupaten Tabanan. Tabanan. https://tabanankab.bps.go.id/publication/ 2017/09/14/c2770b79cc34f57167c2233

8/kecamatan-selemadeg-timur-dalamangka-2017.html

Balitsereal dan Puslitbang Tanaman Pangan. (2007). Jagung: Teknik Produksi dan Pengembangan. In Perkembangan Produksi dan Kebijakan dalam Peningkatan Produksi Jagung (pp. 456461). Pusat Penelitian dan Pengembangan Tanaman Pangan, Departemen Pertanian. Sulawesi Selatan.

http://balitsereal.litbang.pertanian.go.id/b uku-sorgum/

David, F. R. (2004). Manajemen Strategis Konsep-konsep Edisi Kesembilan. PT. Indeks. Jakarta.

Endang Purwanti. (2012). Pengaruh Karakteristik Wirausaha, Modal Usaha, Strategi Pemasaran terhadap Perkembangan UMKM di Desa Dayaan dan Kalilondo Salatiga. Jurnal Among Makarti, 5(9), 13-28. https://jurnal.stieama.ac.id/index.php/am a/article/view/65

Guruh Julio, Kelin Tarigan, \& Salmiah. (2014). Pengaruh Penyuluhan Terhadap Produksi Usaha Tani Stroberi (Kasus: Desa Tongkoh Kecamatan Daulat Rakyat Kabupaten Karo). Journal On Social Economic Of Agriculture And Agribusiness, 3(6), 1-13. https://jurnal.usu.ac.id/index.php/ceress/ article/view/8210

Indika, D. R., \& Jovita, C. (2017). Media Sosial Instagram Sebagai Sarana Promosi Untuk Meningkatkan Minat Beli Konsumen. Jurnal Bisnis Terapan, 1(01), 32. https://doi.org/10.24123/jbt.v1i01.296
Indrawati, K. A. P., Sudiarta, I. N., \& Suardana, I. W. (2017). Efektivitas Iklan Melalui Media Sosial Facebook Dan Instagram Sebagai Salah Satu Strategi Pemasaran Di Krisna Oleh-Oleh Khas Bali. Jurnal Analisis Pariwisata, 17(2), 78-83.

https://ojs.unud.ac.id/index.php/jap/articl e/view/36484

Peraturan Menteri Pertanian Tentang Pedoman Pembinaan Kelompok Tani dan Gabungan Kelompok Tani, Pub. L. No. 82/Permentan/OT.140/8/2013, 55 (2013).

http://perundangan.pertanian.go.id/admi n/p_mentan/Permentan No.82 Tahun 2013.pdf

Purwono, J., Sugyaningsih, S., \& Novianti, R. (2008). Strategi Pengembangan Bisnis Bibit Tanaman Hutan (Kasus PT Sarbi Moerhani Lestari, Bogor). Jurnal Berkala IImu Ekonomi, 2(1), 34-54. https://doi.org/10.21107/NBS.V2I1.560

Rangkuti, F. (2015). Analisis SWOT: Teknik Membedah Kasus Bisnis. Gramedia Pustaka Utama. Jakarta.

Reinhart Abedneju Sondakh, Endang Erawan, \& Sarwo Edy Wibowo. (2019). Pemanfaatan Media Sosial Instagram Pada Akun @Geprekexpress Dalam Mempromosikan Restoran Geprek Express. LImu Komunikasi, 7(1), 279$292 . \quad$ https://ejournal.llkom.fisipunmul.ac.id/site/?p=3812

Safitri, H., \& Setiaji, K. (2018). Pengaruh Modal Usaha Dan Karakteristik Wirausaha Terhadap Perkembangan Usaha Mikro Dan Kecil Di Desa Kedungleper Kecamatan Bangsri Kabupaten Jepara. Economic Education Analysis Journal, 7(2), 792-800. https://journal.unnes.ac.id/sju/index.php/ eeaj/article/view/28291

Setiawan, I. M. D., Sukanteri, N. P., Suryana, I. M., \& Suparyana, P. K. (2019). Pengaruh Promosi Berbasis Sosial Media Terhadap Penjualan Produksi 
Suparyana, dkk. 2020

Kelompok Wanita Tani (KWT) Ayu Tangkas Di Desa Megati. Jurnal IImu Sosial Dan Humaniora, 8(2), 227-234. https://doi.org/10.23887/JISHUNDIKSHA.V8I2.22375

Setiyanti, S. W. (2012). Membangun Kerjasama Tim (Kelompok). Jurnal STIE Semarang, 4(3), 59-65. https://media.neliti.com/media/publicatio ns/132297-ID-membangun-kerja-sama- tim-kelompok.pdf

Untari, D., \& Fajariana, D. I. (2018). Strategi Pemasaran Melalui Media Sosial Instagram (Studi Deskriptif Pada Akun @Subur_Batik). Widya Cipta - Jurnal Sekretari Dan Manajemen, 2(2), 271278.

https://doi.org/10.31294/WIDYACIPTA.V $2 \mathrm{I} 2.4387$ 